\title{
Virulence of Entomopathogenic Nematodes against Meloidogyne incognita for Invasion, Development and Reproduction at Different Application Times in Brinjal Roots
}

\author{
Hafiz Muhammad Aatif ${ }^{1}$, Nazir Javed ${ }^{2}$, Sajid Aleem Khan ${ }^{2 *}$, Salman Ahmed ${ }^{1}$ and Muhammad Raheel ${ }^{2}$ \\ ${ }^{1}$ Department of Plant Pathology, University of Sargodha, Sargodha, Pakistan \\ ${ }^{2}$ Department of Plant Pathology, University of Agriculture, Faisalabad, Pakistan \\ *For Correspondence: sajid_aleem@uaf.edu.pk
}

\begin{abstract}
Keeping in view the staid health and ecological apprehensions coupled with the use of pesticides, entomopathogenic nematodes have the potential to supersede pesticides for the management of various pests. Brinjal is seriously affected by Meloidogyne incognita. Research was conducted on two important groups of nematodes, plant parasitic nematodes (RKNs) and insect parasitic nematodes (entomopathogenic nematodes). Steinernema asiaticum, S. glaseri, Heterohabditis indica and $H$. bacteriophora were evaluated at different time of application against $M$. incognita for invasion, development and reproduction of $M$. incognita. In a life cycle study, $S$. asiaticum and $H$. bacteriophora were proved more effective in influencing the life cycle of RKNs at all application times than S. glaseri and $H$. indica. However all application time of entomopathogenic nematodes (before, with and after) the application of $M$. incognita proved effective as compared to control. $S$. asiaticum and H. bacteriophora delayed penetration of nematode juveniles (J2) into roots of brinjal. (C) 2015 Friends Science Publishers
\end{abstract}

Keywords: Biological control; Entomopathogenic nematodes; M. incognita

\section{Introduction}

The economy of Pakistan is based on agricultural. It is the instant major part of economy, contributes more than $21 \%$ of GDP and absorbs $45 \%$ of employers in the country (Anonymous, 2011).

Eggplant (Solanum melongena L.) is an important low-price summer vegetable. Total production of eggplant in Pakistan is 94.3(000) tons. In Punjab (Pakistan), it was cultivated on an area of 4.7(000) ha with an annual production of 59.2 (000) tons during 2009-2010, with the average yield of 12.6 tons/ ha, which is very low as compared to other Asian countries (Anonymous, 2011). Root-knot nematode [Meloidogyne incognita (Kofoid and White) Chitwood] is widespread and destructive pathogen of brinjal (Fourie and McDonald, 2000). RKNs attack more than 3000 species of plants, including almost all cultivated plants and reduce world crop production by about $5 \%$ losses in individual fields, however may be much higher (Agrios, 2005). Root-knot nematodes Meloidogyne (Goeldi spp.) are recognized as important pests of vegetable crops with a host range of about 100 from different cultivated zones of Pakistan (Zaki et al., 2000). Among the root-knot nematode, $M$. incognita and $M$. javanica are commonly found in the Punjab (Anwar et al., 1991).
Among different nematode management strategies, chemical control has proved generally effective (Barker and Koenning, 1998). But being highly expensive, toxic to plants, livestock, soil micro-flora and fauna (Jairajpuri et al., 1990) and development of resistance in pathogen against these chemicals, governments are demanding environmentally safe chemicals with low toxicity and less mobility to avoid ground water contamination and limited effects on non-target organisms. Therefore, the development and implementation of alternative control strategies are needed.

Entomopathogenic nematodes (EPN) belong to families; Steinernematidae and Heterorhabditidae and kill insects (Grewal et al., 1999, 2005). EPNs is also being used as biological control agents against RKN infesting different crops in the field and green house (Shapiro-Ilan et al., 2006; Molina et al., 2007; Javed et al, 2012).

During 1996-2004, studies on distribution, isolation, biology, taxonomy and efficacy of EPNs have been carried out in Pakistan. The Pakistani species i.e. S. pakistanense have been classified under bicornatum group, while $S$. asiaticum under carpocapsae group (Nguyen, 2004). The advantages of the use of EPNs are many including low cost, high efficacy, safety for humans and other non-target organisms, preservation of other natural enemies, reduction

To cite this paper: Aatif, H.M., N. Javed, S.A. Khan, S. Ahmed and M. Raheel, 2015. Virulence of entomopathogenic nematodes against Meloidogyne incognita for invasion, development and reproduction at different application times in brinjal roots. Int. J. Agric. Biol., 17: 995-1000 
of pesticide residues in food and increased biodiversity in managed ecosystems.

Although there is a very little work has been done on entomopathogenic nematodes in Pakistan. The species Steinernema asiaticum, used in these experiments is a new Pakistani species not used against root knot nematode ( $M$. incognita) before. Keeping in view the importance of the biological control, it was planned to investigate the biological control of root-knot nematodes through EPNs.

\section{Materials and Methods}

\section{Screening of Entomopathogenic Nematodes for the Management of $M$. incognita in Brinjal}

The greater wax moth larva Galleria mellonella L. (Lepidoptera: Galleridae) was used for nematode baiting and produce progeny of nematode isolates. G. mellonela were separated from infected bee hives for nematode culture. The insect culture was reared in $1,500 \mathrm{~mL}$ volume glass containers $(11 \mathrm{~cm}$ diameter and $15 \mathrm{~cm}$ height) on an artificial medium (Wiesner, 1993). Diet with galleria was kept at $27^{\circ} \mathrm{C}$ in an incubator. After reaching last instars, they were taken out from the diet and used for storage and nematode multiplication. Culture of $S$. glaseri, $H$. indica, $H$. bacteriophora collected from Reading University UK, maintained by Ernesto, and S. asiaticum (Local) was maintained on G. mellonella. These were reconfirmed on their morphological basis in Plant Nematology laboratory at University of Agriculture, Faisalabad. Larvae were kept at $15^{\circ} \mathrm{C}$. EPN were collected from dead G. mellonella larvae by modified White trap (White, 1927) and then stored at about $10-15^{\circ} \mathrm{C}$.

Nematodes were always checked for viability before starting experiments. Nematodes were provided oxygen by aerator used for fish aquarium tanks. The number of $M$. incognita used as inoculums in greenhouse experiment always refers to infective $M$. incognita. Only freshly hatched (24-48 h old) were used. For EPNs, only those freshly produced in vivo (less than 2 weeks old) were used.

Brinjal was grown into earthen pots containing 240 $\mathrm{mL}$ formalin sterilized sandy loam soil (72\% sand, $17 \%$ silt and $8 \%$ clay) (Safdar et al., 2012). After four weeks when the plants established their root system, inoculation of plants except control was in the rhizosphere of each plant by making 3-4 holes (Campos and Campos, 2005) and then filled with soil to prevent drying. EPNs were used at the concentration of 2,000 and M. incognita was 1000 per plant. Plants inoculated with only $M$. incognita were kept as control. Treatments were replicated three times. EPNs were applied at three different time intervals (at the same time with $M$ incognita, 5 days before application of $M$ incognita and 5 days after application of $M$ incognita) simultaneously in separate $5 \mathrm{~mL}$ water suspensions by making separate holes of $1 \mathrm{~cm}$ with sharp pointed wood around the base of plants.
Plants were harvested after 35 days to observe the development and reproduction of RKNs factor. After 35 days of inoculation, seedlings of brinjal were soaked along with their pots for 3-4 h. After soaking their roots were gently shaken in a bucket filled with water (washing with a stream of water was avoided to reduce the risk of losing egg masses). After washing shoots of plants were cut off and roots were placed in between two folds of tissue paper to prevent drying. Care was taken in order to limit the loss of small roots and egg masses during the washing procedure. At harvest, to facilitate counting of egg masses, the washed roots were stained with phloxine B (Southey, 1986). Then these were treated $0.1 \%$ acid fuchsin to count total number of females (Bridge et al., 1982).

After staining, roots were wrapped in tissue paper to prevent drying out during the steps of the procedure of evaluation. Stained egg masses from entire root system were counted under a stereomicroscope (Olympus SZ 61) at 2.5X magnification. The whole root system was rated for galling and egg mass presence on a 0 to 5 scale (Quesenberry et al., 1989; Anwar et al., 2007), where $0=$ no gall or egg masses, $1=1-2,2=3-10,3=11-30,4=31-100$, and $5=>100$ galls or egg masses per root system. Experiment was repeated three times.

The data of following parameters was recorded on Fresh weight of root, Number of galls/root system, Number of females, Galling index (No. of egg masses) and Nematode reproduction factor $[\mathrm{Pf} / \mathrm{Pi}]$.

Where $\mathrm{Pf}=$ final nematode population at harvest, $\mathrm{Pi}=$ initial inoculums (1000). Data were subjected to ANOVA by using SAS statistical software (SAS Institute, Cary, NC, USA, 1988) and significant difference among the treatments was portioned by Least Significant Difference Test (LSD) at probability levels of $\mathrm{P}=0.05$ (Steel et al., 1997).

\section{Effect of EPN on Invasion, Development and Reproduction of RKN (M. incognita)}

Two species of EPNs, H. bacteriophora, S. asiaticum were selected, one from each group based on the results of experiment 1 (Table 1) and these were tested against the invasion and development of root knot nematodes. Brinjal was grown into earthen pot containing $240 \mathrm{~mL}$ formalin sterilized soil. After four weeks when the plants established their root system, inoculation was done in different holes with EPNs at the concentration of 2,000 and $M$. incognita 1000 (J2s) per plant in the rhizosphere of each plant by making holes (Campos and Campos, 2005) and then filled with soil to prevent drying. Three replicated pots for each treatment were arranged in completely randomized design and maintained at $25-30^{\circ} \mathrm{C}$ in green house. Invasion/development of root knot nematodes in brinjal plant was studied by staining the roots with acid fuchsin (Bridge et al., 1982). Data was recorded after 7, 17 and 35 days to observe the invasion, development and reproduction of various stages of $M$. incognita. RKN alone treated plants 
were as control. Experiment was repeated three times. The data was recorded on fresh root weight and No. of females per root system. Data were subjected to ANOVA by using SAS statistical software (SAS Institute, 1988) and significant difference among the treatments was portioned by Least Significant Difference Test (LSD) at probability levels of $\mathrm{P}=0.05$ (Steel et al., 1997).

\section{Results}

Screening of Entomopathogenic Nematodes for the Management of $M$. incognita in Brinjal

A preliminary trial was carried out to study entomopathogenic nematodes effects on life cycle of $M$. incognita and its development in a host plant brinjal. The objective of this study was to evaluate the response of Steinernema glaseri, Heterohabditis indica, $H$. bacteriophora and $S$. asiaticum by applying at different time intervals (before, at the same time and after the application of root knot nematodes) for the management $M$. incognita on brinjal $(P<0.05)$. It was assessed by using plant root weight and nematode development parameter (number of galls, egg masses, number of females and reproduction factors).

Root weight of brinjal varied significantly among all treatments. All the EPNs species were significantly different in their effect with respect to root weight (Fig. 1a) as compared to control. When compared average means of EPNs species at all times of applications with root knot nematodes, the maximum root weight was observed in $H$. indica, followed by $S$. glaseri, $H$. bacteriophora and $S$. asiaticum respectively. Minimum root weight was recorded in H. bacteriophora (3.83 g) followed by S. asiaticum (3.84 g) statistically similar $(\mathrm{p}<0.05)$ in all time of application with root knot nematodes. Whereas maximum root weight (5.66) was observed in control where only root knot nematodes were applied.

All the treatments gave significant reduction in root weight as compared to control treatments where only root knot nematodes were applied $(\mathrm{p}<0.05)$. It was observed that there was direct relationship of root weight and number of galls. Maximum root weight was observed in the treatment where the number of galls was the maximum.

At all intervals, all the entomopathogenic species varied in their effect as the number of galls is concerned. All the EPNs species used, proved effective in reducing the number of galls as compared to control. S. asiaticum found to be the most effective at all application time with root knot nematodes followed by $H$. bacteriophora. Less number of galls was recorded in S. asiaticum (152) and it was significantly different from other treatments $\mathrm{p}<0.05$. It was followed by $H$. bacteriophora (170), H. indica (179) and S. glaseri (192) respectively (Fig. 1b). All the application times of entomopathogenic nematodes proved effective (statistically similar) as for as the no. of galls are concern as compared to control.
Table 1: Effect of different species of entomopathogenic nematodes on invasion and development of RKN in Brinjal (after 7 Days)

\begin{tabular}{llll}
\hline Treatments & Root Weight $(\mathrm{g})$ & $\mathrm{J} 2 \mathrm{~s}^{1}$ & $\mathrm{dJ} 2 \mathrm{~s}^{2}$ \\
\hline S. asiaticum $+R K N$ & $1.38^{\mathrm{NS}}$ & $81.3 \mathrm{~b}$ & $31.3 \mathrm{~b}$ \\
S. asiaticum & 1.37 & $0.0 \mathrm{a}$ & $0.0 \mathrm{a}$ \\
H. bacteriophora $+R K N$ & 1.37 & $123.7 \mathrm{c}$ & $71.7 \mathrm{c}$ \\
H. bacteriophora & 1.38 & $0.0 \mathrm{a}$ & $0.0 \mathrm{a}$ \\
RKN alone & 1.38 & $159.7 \mathrm{~d}$ & $166.7 \mathrm{~d}$ \\
\hline
\end{tabular}

${ }^{1} \mathrm{~J} 2 \mathrm{~s}=2^{\text {nd }}$ stage Juveniles, ${ }^{2} \mathrm{dJ} 2 \mathrm{~s}=$ developing $2^{\text {nd }}$ stage Juveniles, ${ }^{3} \mathrm{dJ} 4 \mathrm{~s}=$ developing $4^{\text {th }}$ stage Juveniles

Numbers followed by different letters are significantly different from each other at $p<0.05$

Data is mean of three replications

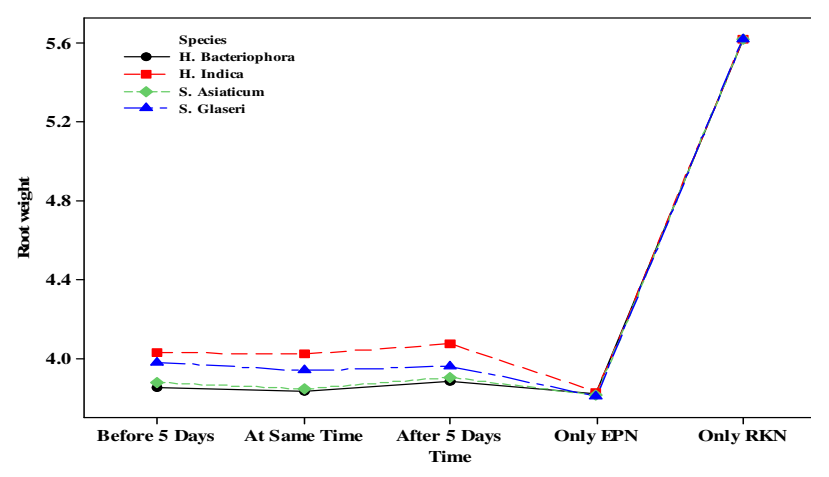

Fig. 1a: Effect of EPN species at different times on root weight of RKN

LDS at $\mathrm{P}=0.05$, Species $=0.0333$, time $=0.0372$, specie ${ }^{*}$ species $=0.0744$

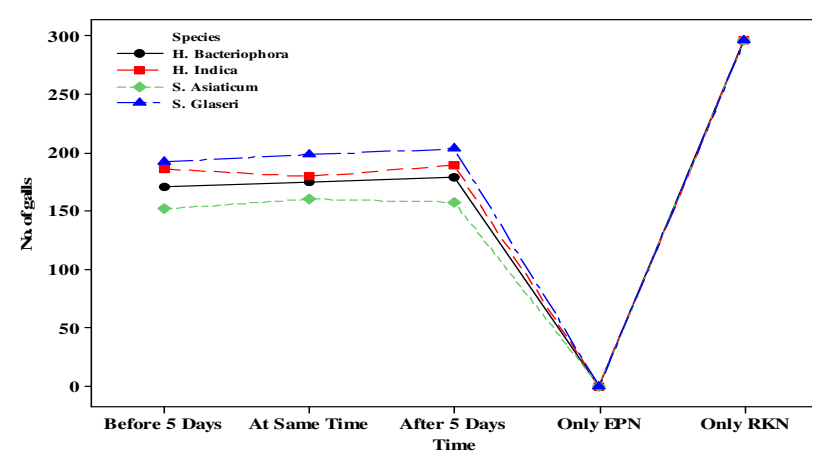

Fig. 1b: Effect of EPN species at different times on number of galls of RKN

LDS at $\mathrm{P}=0.05$, Species $=2.1025$, time $=2.3507$, specie* ${ }^{*}$ species $=4.7014$

Fig. 1c shows that the maximum number of females was recorded in control. All the entomopathogenic nematode species varied in their effects on the number of females. Time of application did not affect the number of females $(\mathrm{p}<0.05)$. Maximum number of females was observed in S. glaseri (228), followed by $H$. indica (221), $H$. bacteriophora (197) and $S$. asiaticum (180) respectively and were significantly $(P<0.05)$ lower as compared to control treatment (322) as given in Fig. 1c $(\mathrm{p}<0.05)$.

As for as the number of egg masses are concerned, the 
best treatment was $S$. asiaticum (92) followed by $H$. bacteriophora (116), S. glaseri (127) and H. indica (153) and these were significantly different from each other at $P<0.05$. While the number of egg masses were maximum (323) in the control where only root knot nematodes were applied (Fig. 1d). Time of application did not significantly affect the number of egg masses $(\mathrm{p}<0.05)$.

Similar trend was observed with reproduction factors. Fig. 1e shows that $S$. asiaticum was the best treatment in reducing the reproduction factors of root knot nematodes with values of 3.026 at all-time intervals $P<0.05$. Highest reproductive potential of root knot nematodes with values of 19.407 were observed with root knot nematodes (control). All the treatments demonstrated upright results as compared to control. Final population of root knot nematodes and rate of reproduction were directly proportional to each other.

\section{Effect of EPNs on Invasion, Development and Reproduction of RKN (M. incognita)}

Two species, H. bacteriophora and S. asiaticum (one from each group) were selected from experiment number 1 , on the basis of their effectiveness against $M$. incognita and reevaluated for their efficacy against invasion, development and reproduction of $M$. incognita at 7, 17 and 35 days of harvesting. Both entomopathogenic nematodes ( $H$. bacteriophora and $S$. asiaticum) and root knot nematodes were applied at same time.

At the first harvest after seven days of inoculation of root knot nematodes and EPNs, root weight did not differ significantly $(P<0.05)$. The reason behind that most of the nematodes were invading the root system but not developing into galls.

Numbers of J2s of root knot nematodes in roots of brinjal were reduced significantly in $S$. asiaticum and $H$. bacteriophora as compared to control. Minimum number of $\mathrm{J} 2 \mathrm{~s}$ were recorded in $S$. asiaticum (81.3) followed by $H$. bacteriophora (123.7), while the maximum number of $\mathrm{J} 2 \mathrm{~s}$ were recorded in control treatment (159.7) where only RKNs were applied. Minimum number of $\mathrm{dJ} 2 \mathrm{~s}$ were recorded in $S$. asiaticum (31.3) followed by $H$. bacteriophora $(71.7)$ and were significantly $(P<0.05)$ lower as compared to control (166.7) as shown in Table 1

At second harvest, after 17 days of application, root weight was recorded minimum in $S$. asiaticum and $H$. bacteriophora (statistically similar) as compared to control where it was maximum (3.67 gm). Root weight was in relation to the number of nematodes invaded into the root. Number of $\mathrm{dJ} 2 \mathrm{~s}$ in all the treatments was significantly different $(\mathrm{p}<0.05)$ as compared to control. These were recorded the maximum in $H$. bacteriophora (43), minimum in S. asiaticum (17), while it was intermediate in control (31). As far as the number of $\mathrm{dJ} 4 \mathrm{~s}$ were concerned, they were recorded minimum in S. asiaticum (67) followed by $H$. bacteriophora (130) and recorded maximum in control (208). Lesser number of $\mathrm{d} J 2 \mathrm{~s}$ and higher number of $\mathrm{dJ} 4 \mathrm{~s}$ in

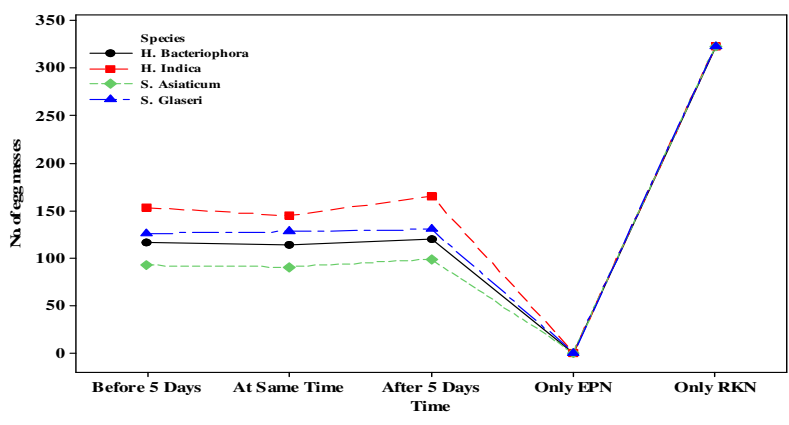

Fig. 1c: Effect of EPN species at different times on number of females of RKN

LDS at $\mathrm{P}=0.05$, Species $=2.2566$, time $=2.5230$, specie ${ }^{*}$ species $=5.0459$

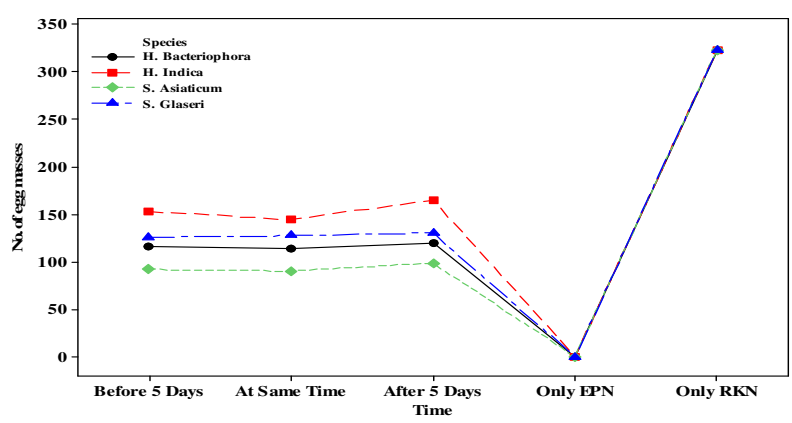

Fig. 1d: Effect of EPN species at different times on number of egg masses of RKN

LDS at $\mathrm{P}=0.05$, Species $=2.4065$, time $=2.6906$, specie ${ }^{*}$ species $=5.3811$

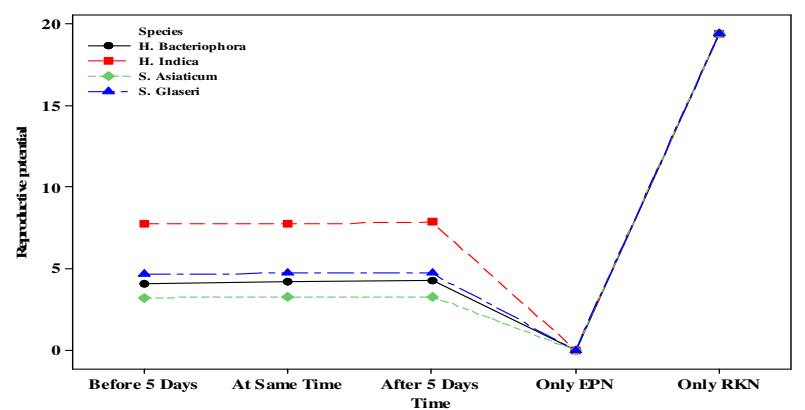

Fig. 1e: Effect of EPN species at different times on reproductive potential of RKN

LDS at $\mathrm{P}=0.05$, Species $=0.1287$, time $=0.1439$, specie $*$ species $=0.2879$

control treatment as compared to $H$. bacteriophora indicate that most of the dJ2s had been passed to the next stage (dJ4s) in control treatment (Table 2). The minimum number of females was recorded in S. asiaticum (31) followed by $H$. bacteriophora (34) statistically similar and were significantly $(P<0.05)$ lower as compared to control treatment (93) as given in Table 2.

At the final harvest after 35 days, root weight of brinjal plants was recorded by applying $H$. bacteriophora and $S$. asiaticum at same time along with root knot nematodes. Influence of both entomopathogenic nematodes species and root knot nematodes alone were also studied. 
Table 3 shows that both the entomopathogenic nematodes species were not significantly differed $(\mathrm{p}<0.05)$ in their effect with respect to root weight. The minimum root weight was recorded in $S$. asiaticum $(3.79 \mathrm{~g})$ fallowed by $H$. bacteriaphora $(3.84 \mathrm{~g})$ statistically similar and were found to be most effective species influencing the root weight as compared to root knot nematodes $(5.64 \mathrm{~g})$.

$\mathrm{J} 2 \mathrm{~s}$ and $\mathrm{d} \mathrm{J} 2 \mathrm{~s}$ found on roots were neglected at this stage. (As the purpose of research was to study only one generation and these were probably of juveniles who were hatched out because there was not any $\mathrm{J} 2$ s present at second harvest (17 days), which showed that all the $\mathrm{J} 2 \mathrm{~s}$ had been passed to the next stage).

Numbers of $\mathrm{d} \mathrm{J} 4 \mathrm{~s}$ were significantly different from each other. These were minimum in $S$. asiaticum followed by $H$. bacteriophora, while maximum number of $\mathrm{dJ} 4 \mathrm{~s}$ was observed in control $(\mathrm{p}<0.05)$.

More a less similar trend was observed in case of number of females, these were recorded minimum in $S$. asiaticum (108) followed by $H$. bacteriophora (201). Maximum females were counted in control (329), where only the root knot nematodes had been applied $(\mathrm{p}<0.05)$ as shown in Table 3.

\section{Discussion}

Plant parasitic root knot nematodes are the most notorious parasites having their presence around the globe, but excessively inhabiting in areas having damp conditions. Root knot nematodes (RKN) not only damage the plants by drawing away nutrients of diseased plants but also affect the fruit quality. Normally, at seedling stage because tissues of the plants roots are tender therefore, the invasion of nematodes is more resulting in heavy losses. Nematodes cause injury usually by entering into the infected tissues, this also facilitates other pathogens to enter through these openings and expedite the losses.

Plants have two types of resistance against RKN including pre-infection and post resistance. Pre-infection resistance is because of the presence of root containing toxic or antagonistic chemicals, which create resistance against puncturing of root knot nematodes in roots (Bendezu and Starr, 2003), whereas an early hypersensitive reaction (HR) operates in post-infection resistance which averts establishment of feeding sites leading to resistance to avoid development of nematodes in host tissues (Haynes and Jones, 1976; Bendezu and Starr, 2003). This is mostly considered that giant cells developed which restrict the activity of xylem. Secondly, rate of photosynthetic activity, because of less light interception and carbohydrate synthesis is also disturbed. This forces the plant to produce more roots in response to the attack of nematode to overcome the damage (Trudgill, 1992).

The objective of this study was to manage the rootknot nematode exploiting the potential of entomopathogenic nematodes $H$. indica, $H$. bacteriophora and $S$. glasseri.
Table 2: Effect of different species of entomopathogenic nematodes on invasion and development of RKN in Brinjal (after 17 Days)

\begin{tabular}{llllll}
\hline Treatments & Root Weight $(\mathrm{g}) \mathrm{J} 2 \mathrm{~s}^{1}$ & $\mathrm{dJ}_{2} \mathrm{~s}^{2}$ & $\mathrm{dJ}_{4} \mathrm{~s}^{3}$ & No. of females \\
\hline S. asiaticum $+R K N$ & $2.67 \mathrm{~b}$ & 0 & $17 \mathrm{~b}$ & $67.3 \mathrm{~b}$ & $31.3 \mathrm{c}$ \\
S. asiaticum & $2.32 \mathrm{a}$ & 0 & $0 \mathrm{a}$ & $0.0 \mathrm{a}$ & $0.0 \mathrm{a}$ \\
H. bacteriophora $+R K N$ & $2.69 \mathrm{~b}$ & 0 & $43 \mathrm{~d}$ & $130.3 \mathrm{c}$ & $34.3 \mathrm{c}$ \\
H. bacteriophora & $2.32 \mathrm{a}$ & 0 & $0 \mathrm{a}$ & $0.0 \mathrm{a}$ & $0.0 \mathrm{a}$ \\
$\mathrm{RKN}$ alone & $3.67 \mathrm{~d}$ & 0 & $31 \mathrm{c}$ & $208.3 \mathrm{~d}$ & $93.7 \mathrm{~d}$ \\
\hline${ }^{1} \mathrm{~J} 2 \mathrm{~s}=2^{\text {nd }}$ stage Juveniles, ${ }^{2} \mathrm{dJ} 2 \mathrm{~s}=$ developing & $2^{\text {nd }}$ & stage & Juveniles, ${ }^{3} \mathrm{dJ} 4 \mathrm{~s}=$ \\
developing $4^{\text {th }}$ stage Juveniles \\
Numbers followed by different letters are significantly different from each \\
other at $p<0.05$ \\
Data is mean of three replications
\end{tabular}

Table 3: Effect of different species of entomopathogenic nematodes on invasion and development of RKN in Brinjal (after 35 Days)

\begin{tabular}{llllll}
\hline Treatments & $\begin{array}{l}\text { Root } \\
(\mathrm{g})\end{array}$ & weight $\mathrm{J} 2 \mathrm{~s}^{1}$ & $\mathrm{dJ}^{2} \mathrm{~s}^{2}$ & $\mathrm{dJ}^{3} \mathrm{~s}^{3}$ & $\begin{array}{l}\text { No. of } \\
\text { females }\end{array}$ \\
\hline S. asiaticum $+R K N$ & $3.84 \mathrm{c}$ & $117 \mathrm{~b}$ & $36.3 \mathrm{~b}$ & $6.33 \mathrm{~b}$ & $108.7 \mathrm{~b}$ \\
S. asiaticum & $3.43 \mathrm{~b}$ & $0.0 \mathrm{a}$ & $0.0 \mathrm{a}$ & $0.00 \mathrm{a}$ & $0.0 \mathrm{a}$ \\
H. bacteriophora $+R K N$ & $3.79 \mathrm{c}$ & $177 \mathrm{c}$ & $83.0 \mathrm{c}$ & $7.33 \mathrm{c}$ & $201.7 \mathrm{c}$ \\
H. bacteriophora & $3.43 \mathrm{~b}$ & $0.0 \mathrm{a}$ & $0.0 \mathrm{a}$ & $0.00 \mathrm{a}$ & $0.0 \mathrm{a}$ \\
RKN alone & $5.64 \mathrm{~d}$ & $312 \mathrm{~d}$ & $311.0 \mathrm{~d}$ & $10.33 \mathrm{~d}$ & $329.0 \mathrm{~d}$ \\
\hline
\end{tabular}

${ }^{1} \mathrm{~J} 2 \mathrm{~s}=2^{\text {nd }}$ stage Juveniles, ${ }^{2} \mathrm{~d} \mathrm{~J} 2 \mathrm{~s}=$ developing $2^{\text {nd }}$ stage Juveniles, ${ }^{3} \mathrm{~d} \mathrm{~J} 4 \mathrm{~s}=$ developing $4^{\text {th }}$ stage Juveniles

Numbers followed by different letters are significantly different from each other at $p<0.05$

Data is mean of three replications

Effect of entomopathogenic nematodes on root knot nematodes $(M$. incognita) were studied by designing different experiments under in vitro conditions. Impact of application time on root knot nematodes in brinjal was studied. Different species of EPN preciously have been reported to control RKN. Pre and post application of $S$. riobravis and S.feltiae@ $25 \mathrm{IJs} / \mathrm{cm}^{2}$ and before application of $H$. bacteriophora against $M$. incognita suppresses the entry and egg production (Perez and Lewis, 2002). Similar results were obtained under in vitro conditions when $H$. bacteriophora, H. indica, S. asiaticum and S. glaseri were applied at the rate of $2000 \mathrm{IJ}$ s/pot. It was revealed that all the species of EPN tested in experiment significantly suppressed $M$. incognita by affecting the invasion of $\mathrm{J} 2$, egg production, number of females and the reproductive potential of RKN at all different times of applications. But our findings are not in line with the results of Perez and Lewis (2004) who concluded that only pre-infestation application was effective; in our research it was found that application of EPNs before at the same time and after the application of root knot nematodes was effective likewise. Our revelations confirming the previous studies in which plant parasitic nematodes were effectively controlled by entomopathogenic nematodes (Somasekhar et al., 2000; Perez and Lewis, 2004). However, application time and species of EPN influence the suppressive effect of EPN against root-knot nematodes (Perez and Lewis, 2002).

In second experiment conducted in pots, $S$. asiaticum 
and H. bacteriophora were investigated for invasion, development and reproduction of root knot nematodes in brinjal roots. Treatments were terminated at various time intervals over a period of 35 days. Reduction was recorded in root knot nematodes along with reduced number of galls per root system, number of egg masses and number of females in EPN treated roots. From this, it was inferred that it might be due to crowding effect of EPN, nematicidal properties of metabolites and their allopathic effects which was influencing the life cycle and maturity of RKN (Hu et al., 1999; Lewis et al., 2001). Different factors, like competition between nematode groups for $\mathrm{CO}_{2}$, space in rhizosphere and other root exudates assist the entomopathogenic nematodes to create suppressive effects on plant-parasitic nematodes (Robinson, 1995; Tsai and Yeh, 1995).

Furthermore, behavioral response of nematodes, increased population of natural enemies and predators in the production of allelochemicals by the entomopathogenic nematodes and symbiotic bacteria complex are also considered important factors enhancing the potential of EPN against RKN (Lewis et al., 2001). Present study will be helpful for the management of root knot nematodes.

\section{Conclusion}

Attack of $M$. incognita seriously affected the brinjal shoot and especially root growth. However, application time of entomopathogenic nematodes (before, with and after) were quite effective in reducing the population of $M$. incognita as compared to control.

\section{References}

Agrios, G.N., 2005. Plant Pathology, $5^{\text {th }}$ edition, p: 574. Acad. Press, USA Anonymous, 2011. Agriculture Statistics of Pakistan, pp: 12-13. Govt. of Pakistan, Ministry of Food and Agriculture, Food and Agriculture Division. (Economic Wing), Islamabad

Anwar, S.A., A. Zia, M. Hussain and M. Kamran, 2007. Host suitability of selected plants to Meloidogyne incognita in the Punjab, Pakistan. Int. J. Nematol., 17: 144-150

Anwar, S.A., S. Gorsi, M. Anwar-ul-Haq, T. Rehman and P. Yousuf, 1991. Plant parasitic nematodes of some field, vegetable, fruit and ornamental crops. J. Agric. Res., 29: 233-249

Barker, K.R. and S.R. Koenning, 1998. Developing sustainable system for nematode management. Аnпи. Rev. Phytopathol., 36: 165-205

Bendezu, I.F. and J. Starr, 2003. Mechanism of resistance to Meloidogyne arenaria in the peanut cultivar. J. Nematol., 35: 115-118

Bridge, J., S. Page and S. Jordan, 1982. An improved method for staining nematodes in roots. Rep. Rothamsted Exp. Stn., 1: 171

Campos, H.D. and V.P. Campos, 2005. Studies on inoculum, inoculation and extraction of root-knot nematodes, Meloidogyne javinaca. Nematol. Brasil, 29: 75-82

Chitwood, B.G., 1949. Root-knot nematodes. Part I. A revision of the genus Meloidogyne (Goeldi, 1887). Proc. Helminthol. Soc. Washington, 16: $19-104$

Fourie, H. and A.H. McDonald, 2000. Nematodes. ARCLNR Leaflet. Crop Prot. Ser., 18: 4

Grewal, P.S., E.E. Lewis and S. Venkatachari, 1999. Allelopathy: A possible mechanism of suppression of plant-parasitic nematodes by entomopathogenic nematodes. Nematology, 1: 735-743

Grewal, P.S., R.U. Ehlers and L. Shapiro, 2005. Nematodes as Biological Control Agents. CABI Publishing, Oxon, UK
Haynes, R.L. and C.M. Jones, 1976. Effects of the Bi locus in cucumber on reproduction, attraction and response of the plant to infection by the southern root-knot nematode. J. Amer. Soc. Hortic. Sci., 101: 422-424

Hu, K., L. Jianxiong and J.M. Webster, 1999. Nematicidal metabolites produced by Photorhabdus luminescens (Enterobacteriaceae), bacterial symbiont of entomopathogenic nematodes. Nematology, 1: 457-469

Jairajpuri, M.S., M.M. Alam and I. Ahmad, 1990. Nematode Biocontrol, Aspects and Prospects, p: 152. CBS Publication Dist. Pvt. Ltd. Dehli, India

Lewis, E.E., P.S. Grewal and S. Sardanelli, 2001. Interaction between the Steinernema feltiae-Xenorhabdus bovienii insect pathogen complex and root-knot nematode Meloidogyne incognita. Biol. Cont., 21: $55-62$

Molina, J.P., C. Dolinski, R.M. Souza and E.E. Lewis, 2007. Effect of entomopathogenic nematodes (Rhabdita: Steinernematidae and Heterorhabditidae) on Meloidogyne mayaguensis Rammah and Hirschmann (Tylenchida: Meloidoginidae) infection in tomato plants. J. Nematol., 39: 338-342

Javed, N., S.A. Khan, I. U Haq, M. Atiq and M. Kamran, 2012. Effect of Steinernema glaseri and $H$. indica on the plant vigour and root knot nematodes in tomato roots at different densities and time of applications. Pak. J. Zool., 44: 1165-1170

Nguyen, K.B., 2004. 37 Species of Steinernema. Entomology and Nematology Department, University of Florida

Perez, E.E. and E.E. Lewis, 2002. Use of entomopathogenic nematodes to suppress Meloidogyne incognita on greenhouse tomatoes. $J$. Nematol., 34: 171-174

Perez, E.E. and E.E. Lewis, 2004. Suppression of Meloidogyne incognita and Meloidogyne hapla with entomopathogenic nematodes on greenhouse peanuts and tomatoes. Biol. Cont., 30: 336-341

Quesenberry, K.H., D.D. Baltensperger, R.A. Dunn, C.J. Wilcox and S.R. Hardy, 1989. Selection for tolerance to root-knot nematodes in red clover. Crop. Sci., 29: 62-65

Robinson, A.F., 1995. Optimal release for attracting M. incognita, Rotylenchus reniformis and other nematodes to carbon dioxide in sand. J. Nematol., 27: 42-50

Safdar, H., N. Javed, S.A. Khan, I.U. Haq, A. Safdar and N.A. Khan, 2012. Control of Meloidogyne incognita (Kofoid and White) Chitwood root knot nematodes by Cadusafos (Rugby®). Pak. J. Zool., 144: 703-1710

SAS Institute, 1988. SAS/STAT User's Guide. Release 6.03 Edition $6^{\text {th }}$ edition. SAS institute Inc., North Carolina, Cary, Inc. USA

Shapiro-Ilan, D.I., A.P. Nyczepir, E.E. Lewis, 2006. Entomopathogenic nematodes and bacteria applications for control of the pecan rootknot nematode Meloidogyne partityla in the greenhouse. J. Nematol., 38: $449-454$

Somasekhar, N., P.S. Grewal, A.B.E. Nardo and B.R. Stinner, 2002. Non target effect of entomopathogenic nematodes on the soil nematode community. J. Appl. Ecol., 39: 735-744

Southey, J.F., 1986. Laboratory Methods for Work in Plant and Soil Nematodes, p: 202. Ministry of Agri. Fisheries and Food, London

Steel, R.G.D., J.H. Torrie and D.A. Dickey, 1997. Principles and Procedures of Statistics: A Biometric Approach, $3^{\text {rd }}$ edition. McGraw Hill Book Co. Inc. New York, USA

Trudgill, D.L., 1992. Resistance and tolerance of plant-parasitic nematodes in plants. Annu. Rev. Phytopathol., 29: 167-192

Tsai, B.Y and H.L Yeh, 1995. Effect of Steinernema carpocapsae Weiser on the infectivity of Pratylenchus coffeae (Zimmermann) FilipJev \& Schourmans Stekhoven and Meloidogyne javanica (Treub) Chitwood. Plant Prot. Bull., 4: 106

White, G.F., 1927. A method for obtaining infective nematode larvae from cultures. Science, 66: 302-303

Wiesner, A., 1993. Die Induktion der Immunabwehr eines Insekts (Galleria mellonella, Lepidoptera) durch synthetische Materialien und arteigene Haemolymphfaktoren. Berlin, Germany

Zaki, M.J., 2000. Biomanagement of Root Knot Nematodes Problem of Vegetables, p: 131. DFID, UK, Research Project Report. Department of Botany, University of Karachi, Pakistan

(Received 29 August 2013; Accepted 15 July 2014) 